\title{
ЕСТЕТСКА (РЕ)КОНСТРУКЦИЈА НА ЕДНА ТРАУМА
}

\author{
Дамјана Ивановска \\ Кинотека на Македонија, Скопје \\ damjanaivanovska@gmail.com
}

Човекот е во постојана врска со реалноста околу себе и врз основа на постапките, мислењата и одлуките тој го создава сопственото јас, кое неминовно е условено од релацијата меѓу себството и Друг̄иой. Идентификацијата станува цел за да се премине непремостливот јаз, оној кој секогаш создава поделби во себството и го поттикнува затворањето во себеси.

Како примери кои во својата приказна ја инкорпорираат релацијата персона - реалност - идентитет, но кои, исто така, ги актуализираат и проблемите на градење на идентитетот, траумата која длабоко се вовлекува во составот на таквите напори, односот кон Друг̄иой и, најпосле, постапката на кршење (разградување) на проектираната стварност и подривање на основата врз која е изградена - се филмовите: Персона на Ингмар Бергман (Ingmar Bergman 1966), Очи широко зайворени на Стенли Кјубрик (Stanley Kubrick 1999), Булевар на sвезgииее на Дејвид Линч (David Lynch 2001) и Нейоврайно на Гаспар Hоа (Gaspard Noé 2002).

Траумата која се случува во секој од овие филмски наративи е почетен импулс на т.н. метаморфозирање (дублирање), кое го пресвртува светот кој е поставен пред гледачите.

Клучни зборови: траума, подвоеност, персона, идеално-јас, идентитет, конфликт 


\title{
AN AESTHETIC (RE)CONSTRUCTION OF A TRAUMA
}

\author{
Damjana Ivanovska \\ Cinemateque of Macedonia, Skopje \\ damjanaivanovska@gmail.com
}

The man is in constant relation to the reality surrounding him and based on his actions, opinions and decisions he creates his own $I$, which is inevitably conditioned by the relationship of himself - and the Other, in order to surpass the unbridgeable gap, which forever separates him and makes him closed.

Examples which show in their story how to incorporate the relation person - reality - identity, but which also incorporate problems of building identity, at the same time as deeply immersed trauma, the relation towards others and, in the end, the procedure for breaking (disintegrating) the projected reality and undermining the basis on which it was built on - previously accepted values of the Good, Beautiful - are the films Persona (Ingmar Bergman, 1966), Eyes wide shut (Stanley Kubrick, 1999), Mulholland Drive (David Lynch, 2001) and Irreversible (Gaspard Noé, 2002).

Trauma, which penetrates into each of these film narratives is a starting impulse of metamorphosing (doubling), that recreates the world that is imposed in front of the viewers.

Key words: trauma, doubling, persona, ideal-I, identity, conflict 
Човекот е во постојана врска со реалноста околу себе, тој врз основа на постапките, мислењата и одлуките го создава сопственото јас, кое неминовно е условено од релацијата меѓу себството и другоста, но кое вложува напори за надминување на непремостливот јаз, оној кој секогаш поттикнува поделби и опстојува во нас.

Во таа насока, субјектот, човекот го создава својот идентитет, но истовремено го реализира во однос кон реалноста во која ги воспоставува своите вредности како основа на постоењето, а кои честопати подлегнуваат на кршење и разградување. Токму таквите прашања ја градат релацијата субјект-идентитет-реалност и судирите кои произлегуваат од нивното несовпаѓање.

Како примери кои во својата приказна ја инкорпорираат релацијата персона-реалност-идентитет, но кои, исто така, ги вовлекуваат и проблемите на градење на идентитетот, траумата која длабоко погодува, односот кон Друг̄иой и на крајот постапката на кршење (разградување) на проектираната стварноста и подривање на основата врз која е таа изградена (според однапред прифатените вредности на добро и убаво), се филмовите: Персона на Ингмар Бергман (Ingmar Bergman 1966), Очи широко зайворени на Стенли Кјубрик (Stanley Kubrick 1999), Булевар на sвезguтее на Дејвид Линч (David Lynch 2001) и Нейоврайно на Гаспар Hoa (Gaspard Noé 2002).

Ако проблемот го поставиме во однос со личноста која низ реалноста се движи преземајќи ги различните маски што би ѝ овозможиле полесен премин низ и соочување со реалноста, секогаш средбата со Друг̄иот̄, со кој се дели таа иста реалност, станува потенцијална закана за опстанокот и насилството кое неминовно се појавува.

Ако можеме да ги поставиме овие филмски текстови во однос и да ги толкуваме како парови, тогаш тие би се состоеле од Алма и Елизабет, Бети и Рита, Бил и Алис, но и тројката Алекс, Маркус, Пјер, зашто „за да се посведочи несвесното се потребни двајца“", како што истакнуваат Фелман и Лауб, парафразирајќи го Фројд (Felman and Laub 1993: 13).

Иако овие дела се создадени во различни години и од различни режисери, тие се поврзани во многу аспекти кои се особено значајни кога станува збор за релацијата на поткопувањето на јазикот кој не успева да користи како средство за надминување на вечниот јаз кој стои меѓу нас и оној другиот.

Траумата која се актуализира во секој од овие филмски наративи, без разлика дали е прикажана преку насилството во Нейоврайно, или пак, е претставена во вид на реминисценција како во наративната структура на филмот Персона, или е навестена во вид на исповед на брачниот партнер 
за неговата сексуална фантазија, како во филмот Очи широко заивворени или пак, се појавува во вид на кодирани слики, бои и кадри каде што е нагласена до степен на извештачено глумење или користење на т.н. „глума на филм“, како во филмот Булевар на sвезgийе, таа во сите случаи е почетен импулс на т.н. метаморфозирање (дублирање) кое го пресвртува светот кој е поставен пред гледачите.

Проблемот на дезинтеграција која го означува распадот на себството ја содржи основната проблематика на личноста која се метаморфозира како суштински дел од создавањето, менувањето и кршењето на маската составена за да се задоволи општествената потреба за припаѓање.

Според Џон Лок, претставникот на англискиот емпиризам, личноста или поточно личниот идентитет преставува конструкција која неминовно е поврзана со меморијата, со искуството и со општествената состојба. „Личноста е фигура на и за социјалноста“ (Clift 2004: 52). Но, исто така, социјалниот контекст на креирањето на улогата и вербалната способност таа улога да се именува е поткопана во моментот кога јазикот се појавува како проблематично средство за комуникација.

„Идентитетот е стабилизирано искуство за себеси, не како што е искусено во моментот на чиста или на неограничена себеопсервација, туку идентитет кој е стабилизиран преку јазикот - имено, преку актот на именувањето на себството, на „Јас““ пред погледот на другите“ (Clift 2004: 53).

Особено значајно е да се погледне проблемот поврзан со поимот „person“ (персона) како што е наведено од страна на авторката Сара Клифт (Clift 2014). Според Оксфордскиот речник, „персона“ во 17-тиот век ги содржи конотациите кои се дел и од размислувањата на Лок за „самосвесно или рационално суштество“, но, исто така, персона значи и улога играна во драма, потоа поимот се однесува на субјект кој има права и обврски пред законот. Додека пак, во македонскиот речник, според буквалниот превод, зборот „персона“ во себе ги има апсорбирано негативните квалификации:

\section{иерсона}

мн. персони

Вид збор: именка, женски род

\section{1. личност, особа}

англиски: person

албански: person

Употреба: иронично, книжевен збор



\section{2. (за жена или маж) физички крупна личност}

англиски: person 
албански: grua ose burrë hijerandë

Употреба: разговорно

Пример: Таа е иеерсона

Токму тука може да се согледа дека тоа градење на „личност“ во својата повеќенаменска фасетност, секогаш „имплицира потенцијална поделеност (дуплицираност) која, исто така, може да биде маска, измама, средство за престорување, и најважно, фикција која може да ја преземе ликот на Друг̄иой“"(Clift 2004: 54). Од друга страна пак, маската на личноста во себе крие уште една можност, една можност за непристојна или лажна персона.

Сепак, во овие филмски остварувања ликовите се движат низ настани и сеќавања, соништа, кои симболично ги отсликуваат нештата.

Пустелијата на островот во Персона, лавиринтот од градски улици во Очи широко зайворени, црвените соби за забранети сексуални задоволства во клубот „Ректум““, кој наликува на дигестивниот тракт, или пак, замаглената камера претопена во светлина во „Булевар на звездите“ се просторите кои значително го објаснуваат движењето во филмската нарација.

Оттука сосема е оправдано ако се упатиме кон интерпретација на филмот Персона каде што двете жени - Елизабет и Алма - ги претставуваат двете крајности во кои може да се оствари личноста: молкот како прототекст на крајното исклучување на означувањето и наивната брборливост која, со отсуство или со непредизвикување на одговор, прибегнува кон насилство.

Во филмот Персона на Ингмар Бергман, филмското дејство е вметнато во т.н. филмска рамка која, според Сузан Сонтаг, ја засилува темата на удвојување (doubling) (Sontag 1975: 73). Непријатната белина на екранот настаната со палењето на карбонската прачка, трепкањето на филмската лента, влегувањето во проекторот е применето со цел филмот да се претстави како објект. Удвојувањето на филмот во прологот завршува во удвојување на сликата на ликовите на две жени на еден голем екран.

Алма и Елизабет во движењето и во обидите за меѓусебна комуникација ја откриваат недоволноста на молкот и јазикот како средства за формирање на маската и персоната. Познатата актерка во мигот на остварување на својата улога на сцената замолкнува, а следствено на тоа одбива какво било движење на телото, додека пак Алма ја препознаваме по униформата на медицинска сестра. Психијатарот ѝ објаснува на медицинската сестра Алма дека нејзиниот пациент е актерка која за време на својата изведба на ликот на Електра замолчела на самата сцена. Таа се наоѓа во состојба на парализа, која трае три месеци, и покрај тоа што ментално и физички е здрава. Во реалниот свет, актерката одбива да прифати каква било зададена улога зашто тоа бара откажувања и дефинирања во строги рамки преку изрази, преку облека, движења и многу други детерминираности. 
Но, исповедувањето на Алма, покрај молкот на Елизабет, кој значи и отсуство на осудување/оправдување, е оној пресвртен момент кога таа ја сфаќа недоволноста на јазикот да ја искаже фрустрацијата преку зборовите кои се распаѓаат во моментот кога се добива желба за искажување од кое не произлегува одговор.

Кршењето на двете маски ги покажува празнините кои зборовите не можат да ги исполнат со значење и ја соголува вистината која е празна, што е причина за фрустрација, суровост и насилство. Зборовната конструкција на маската неминовно е составена од овие празнини во означувањето, објаснува Сузан Сонтаг. Таа вели,

Ако одржувањето на личноста бара задржување на интегритетот на маската, а вистината за личноста е секогаш во кршењето на таа маска, тогаш вистината за животот во целина е врзана за распрснувањето на целосната фасада зад која се крие апсолутната суровост. (Sontag 1975: 59)

Насилството на крајот од филмот е претставено во својата најстрашна форма, тоа е изразено во формите на самоуништување и самоповредување и ја открива фрустрацијата од маската чие вадење е неотповикливо.

Поврзаноста на овие филмови би било соодветно да ја гледаме низ призма на тезата за огледалната фаза на Лакан, кој вели дека: „'Идеалното-јас'... е извор на второстепени идентификации во кои терминот 'Јас' ги содржи функциите на либидалната нормализација“ (Lacan 1949: 56). Тоа „идеалнојас" е онаа праслика од огледалото според која се создава улогата која најмногу соодветствува на она што сакаме да бидеме. Огледалната фаза е, всушност, оној дел од животот на човекот кога тој го гради својот идентитет и, во него, тој го спознава своето постоење како различно, но, исто така, во него се крие сликата за она што сака да биде, она што соодветно би сакал да се совпадне со реалноста.

Бети/ Дијана Селвин во првиот дел од филмот „Булевар на sвездите“ е млада и навина девојка која доаѓ во светот на славните каде што посакува да ја оствари својата илузија. Во него само успешните, талентираните и вредните успеваат да го достигнат идеалот на „,вездата“, а потоа се соочуваат со ужасите на стварноста. Како свој избор на професија го определува актерството, кое ќе овозможи трансформација во различни улоги, а меѓу нив најидеалната улога е онаа на актерот/филмската звезда. Сепак, претставата за „персоната“ е, исто така, активна и во сонот на Дијана Селвин, т.е. Бети Елмс, која навлегува во светот на Боговите (Холивуд), во чии рамки ја создава проекцијата за себе како актерка со талент којашто ќе успее да се претстави на големото платно. Таа е посветена, таа е самоуверена и веќе има остварено одреден успех, а тоа е победа на натпреварот во танцување 
(jitterbug competition, тоа е танц кој бара голема физичка подготвеност од танцувачите, но и силна потреба за истакнување на формите и чекорите на движење изведувани со свинг-музика).Токму во овие моменти, Линч го спротивставува кадарот каде што полека гледачот влегува во црвената постела и легнува на црвената перница и тука се означува влезот во филмот, односно во сонот, таму каде што сѐ е илузија, конструкција, таму каде што за сѐ говориме како за „ау по banda“.

Нејзината идеална жена е Рита (Рита Хејворд, убавицата од златната епоха на Холивуд), која доаѓа во домот на Бети во состојба на амнезија по доживеаната сообраќајна несреќа на автопатот „Мулхоланд драјв“ и која бара засолниште. Наивната Бети (Дијана Селвин) и Рита (нејзиниот сексуален идеал, Камила Роудс) се движат во еден свет кој е пресликан, метаморфозиран, адаптиран свет од соништата, во кој нивна задача е да го откријат идентитетот, да ја најдат целта на синиот клуч и кутијата. Од домот тие започнуваат потрага по идентитетот на Рита.

Сепак, уште на самиот почеток, Линч на гледачот му претставува една приказна која е силно обележана со множество симболи и со мали вметнати дополнувања во форма на екскурси, кои ја усложнуваат позицијата на оној кој има задача да толкува и да разбира. Една од тие навидум неповрзани сцени е сцената во ресторанот „Винкис“ каде што се случува средбата на сонувачот со „неговото“ чудовиште. Разговорот започнува како разговор меѓу пациент и психијатар, пациентот раскажува дека веќе по втор пат во еден самрак го отсонувал чудовиштето во задниот дел од ресторанот. Но, најсилниот момент е моментот кога тој ќе се сретне со она што го сонувал, она „реално“, она кое од манифестација во сонот станало реалност. Сонот е она што го заштитува од чудовиштето. „Се надевам дека никогаш нема да го видам тоа лице надвор од сонот“. Но средбата со чудовиштето се случува и во суровата реалност. „Винкис“ е местото каде што Дијана Селвин (Бети) работи и каде што таа го нарачува убиството на својата пријателка Камила.

Во иста насока тече и приказната за режисерот Адам, кој наспроти очекувањата да ја има режисерската палка во своите раце, открива дека неговиот филм е диригиран од страна на продуцентите. Комичноста на целата таа приказна функционира на две рамништа. На првото рамниште имаме стереотипна приказна раскажана во форма на ситком-верзија за неверната жена која го исфрла од домот и на второто рамниште се случува средбата со каубојот кој објаснува дека нештата мора да бидат адаптирани, дека околностите се онакви какви што се и Адам мора се прилагоди на нив. Ако креацијата и создавањето на филмот не подразбира целосен авторитет на режисерот врз делото, филмот, тогаш тој, во судир со центрите на моќ, го допира дното и е лишен од високиот статус на режисер, од богатството, од угледот, од парите. Каубојот е митската фигура од фантазијата за 
несовладливата машкост и издржливост во американската популарна култура, тој е воведен како симболичен лик кој треба да донесе помирување на Адам со улогата која мора да ја преземе за да преживее.

Приказната за чудовиштето во ресторанот „Винкис“ е метафора за уништувањето кое дејствува кога постојат несогласувања со реалноста, што резултира со смртоносни последици, додека пак приказната за каубојот е приказна за надминувањето на оваа состојба на негирање и влегување во улогата која го заштитува субјектот од суровоста на реалноста. Сонот на Бети е сон кој наликува на реалноста, но со поинаку распределени улоги во кои само таа ја пронаоѓа смислата. Бети во сонот ја конструира својата партнерка Рита како жена на која таа ѝ е потребна за да се пронајде себеси, но истовремено таа е и жена/идеал кон кој се стреми, меѓутоа во тоа не успева.

Метаморфозирањето, дублирањето што Линч го презема од филмот Персона во „Булеварот на звездите“ со застрашувачка моќ е претставено во секој кадар кој го покажува движењето на Бети во обидот да ја разреши мистеријата и да го „освои“ Холивуд. Секој детаљ, секој лик, секој симбол во сонот ја претставува первертираната страна на реалноста, но овојпат устроена онака како што ја создава Бети. Чудовиштето кое стои „зад неа“ е оној аспект кој трпеливо ја чека својата шанса да се појави. Сонот за чудовиштето кое чека кај контејнерите со отпадоци е сон во сон, зашто репресијата е силна и функционира на подлабоко ниво на потсвеста. Исто како сон во сон, глумата во сонот претставува форма со која свеста ја искажува траумата произлезена од непосакуваниот сексуален однос со повозрасни мажи искажан со лоша глума „каде што не треба да се глуми реално, сѐ додека тоа не стане реално“ и каде што има изразена сексуална конотација уочлива во репликата која гласи: „Кажи ми каде те боли, бејби“.

Студиото е место каде што треба да се реализираат сите соништа и да се стане филмска „,везда“, но во ова место каде што треба да се достигне вистинската реализација, Бети го преживува трауматичниот дел од нејзината стварност, овој пат одглумена преку аудиција за филм. Соодветна паралела може да се препознае и во постарите женски фигури кои под своја закрила ја преземаат Бети, тетката Рут која го отстапува својот дом и кастингагентката Лини Џејмс, која е значаен лик кој ги распределува улогите и ги изведува аудициите. Големата улога, заради која вреди да се умре е улогата за која е предодредена Камила Роудс. „Тоа е таа девојка“ е реченицата која Адам мора да ја каже и со која ќе потврди дека одлучил да се помири со барањата на продуцентите.

Оттука започнува патешествието на двете девојки, Рита и Бети, кои влегуваат во „Сиера Бонита“, комплекс од апартмани кои се дел од 
сиромашен кварт. Русокосата девојка облечена во светла облека и бринетата која на себе ја носи црвената боја заедно го пронаоѓаат полураспаднатото тело во креветот.

Промената на изгледот и францускиот речник, односно обидите за востановување нов идентитет наместо шпанскиот, се очајнички во смисла на реалната трансформација и реализација на Бети во нова улога, таа и овој пат е спречена. Таа доживува преобразба со цел да се заборави минатото и да се создаде однос кон реалноста. Бети, преку ликот на Рита остварува лажна трансформација, која се случува на рамниште на појавноста. Периката ја означува површинската промена, но таквата трансформација е далеку од длабинска промена и освестување. Кога нивниот изглед ќе почне да се менува се достигнува ново рамништето на кое во сликата двете достигнуваат соединување во креветот.

По оваа сцена следува посетата на театарот каде што пред нив се одигрува последниот обид за соочување со реалноста и траумата. Бети е облечена во црвена блуза, додека пак Рита е облечена во црна облека што треба да ја поврзе и да ја изедначи со темнината. Кога магионичарот ја прикажува илузијата, телото на Бети започнува да трепери и веќе е очигледно кршењето на она што претставува конструкција на Бети во сонот. Исчезнувајќи во чадот, магионичарот станува страшниот волшебник од О3, кој на крајот само ја открива вистината дека сѐ е лага, сон, фантазија, составена во умот на Бети/ Селвин. Од местото зад виножитото, местото на соништата, каков што е Холивуд, преку песната Lorando, која е песна за неостварената љубов, се случува преминот кон последната фаза во која се реализира последниот обид за отклучување на сината кутија со помош на синиот клуч.

Во тој момент Дејвид Линч го прави преминот од она што е сон во она што е стварност, а во тој премин Бети исчезнува. Рита мора да ја отклучи сината кутија, а со тоа го отвора влезот во стварноста. Каубојот е оној кој ја повикува убавата девојка да се разбуди.

Гледачот полека осознава дека Бети е всушност Селвин. Неугледноста на апартманот и болката која се чувствува е онаа која не соодветствува на однесувањето и среќните насмевки на Бети, а Рита е Камила Роудс, партнерката која си заминала. Ова соочување со реалноста, за гледачот значи задача одново да ги прераспредели значењата на нештата, Холивуд е местото каде што Дијана не успеала да се оствари себеси. Тоа е место на пропаднатата шанса да се биде познат, славен и богат, па затоа траумата е значително засилена. Конечно се согледува дека успехот во Холивуд не зависи од талентираноста, туку од поинакви вредности. Маргиналните улоги кои таа ги добивала се добиени благодарение на Камила, која успева да постигне успех во овој свет на Боговите преку љубовната врска со 
режисерот Адам. Самозадоволувањето под таквите околности станува невозможно, надминувањето на болката е неостварливо и се преминува кон фазата на самоуништувањето, самоубиството.

Нејзиното искачување по Булеварот на звездите (Mulholland drive) е искачување по кое гледачот започнува да ги препознава нештата. Коко, повеќе не е добронамерна домарка, туку мајката на Адам, режисерот и свршеникот на Камила, Дајен, открива дека доаѓ од Канада, победила на натпревар за танц, починатата тетка е онаа која ѝ ги оставила куќата и парите, а со Камила остварила средба и врска за време на снимањето на филмот Приказнайа за Силвија Норӣ.

Во последните секвенци од филмот, на еден оригинален начин, Дејвид Линч го претставува чудовиштето или траумата која ја поседува сината кутија од која излегуваат родителите на Дајен. Убиството е извршено, Дајен не е во состојба да го поднесе тоа засилено брборење на родителите, тропањето на вратата, врисоците, па во одбрана од нив, таа конечно го повлекува чкрапалото на пиштолот и во чадот се соединува со чудовиштето.

Сонот е сферата каде што таа ги оформува настаните според устројство кое посакува да го оствари, зашто откако реалноста на Холивуд се претставува како несоодветна на онаа замисла која таа ја имала за тоа место, нејзината личност не успева да ја задржи маската, персоната која треба да ја облече. Траумата од сознанието дека тој свет е само илузија, дека не постојат невините нешта кон кои таа постојано се стреми за да го избегне соочувањето со неуспехот во животот сведен на сексуална злоупотреба, неостварена љубов, пропаѓање, е поврзана со фактот дека не успеала целосно да се реализира.

Сепак, оваа проблематика на навлегување во траумата, како кршење и неможност да се формира персоната/ликот за определена реална ситуација е тема и во последниот филм на Стенли Кјубрик, Очи широко зативорени, кој е работен врз книжевната предлошка, а тоа е новелата на Артур Шницлер, Новела за соной. Филмот Очи широко зайворени е филм во кој брачните партнери Бил и Алис кои уживаат одреден општествен статус, кои веќе изградиле дом, а Бил има значаен професионален успех на доктор, оној кој треба да се погрижи за здравјето на своите пациенти, кој е морално доследен, одеднаш се соочуваат со најрадикалното подривање на границите на она што Лакан го нарекува Umwelt (опкружување) и Innenwelt (внатрешен свет) (Lacan 1946: 60).

Тие се брачна двојка чија интимност, Кјубрик ја конструира низ мошне прецизни детали. Нивната интимност е до толкава мера длабока, што вршењето на физиолошката потреба на жената се остварува пред нејзиниот партнер. Надворешниот изглед на оваа брачна двојка која на Божиќната 
забава ја прикажува својата целосна посветеност и тоа кога тие се соочени со предизвикот на прељубата станува основа врз која се будат фантазиите.

Алис, иако е во алкохолизирана состојба и очигледно заведена од

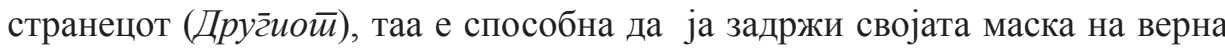
жена која го бара својот сопруг, иако, во својата фантазија, таа веќе еднаш се откажала од целиот живот со него. Затоа, според Жижек, кој го чита Лакан низ овие филмски наративи, „фантазијата е платно кое не заштитува од средбата со Реалноста, самата фантазија, во својата основа - она што Фројд го нарекува ‘фундаментална фантазија' - која ги овозможува елементарните координати на способноста на субјектот за желба (посакување), никогаш не може да биде субјективизирана и мора да остане репресирана со цел да функционира“" (Žižek 2006: 59). Фантазиите на Никол Кидман кон офицерот заради кој таа би се откажала од сѐ, или пак нереализираните фантазии на Том Круз кои се, исто така, попречени, стопирани, дури би рекла и импотентни, треба да добијат форма, а со тоа и реализација.

Овие изливи и вербални остварувања на нивните фантазии го предизвикуваат немирот, кршењето на реалноста (која е конструкција за самозаштита и која гарантира живот низ различните аспекти: општество, болница, дом, брачна постела, таа мора да биде поправена, повратена, одново здобиена со потребата за враќање кон новата фантазија којашто и двајцата мора да ја споделат, но, сепак, различно да ја конструираат). Траумата во овој филм е соочувањето со фантазијата на Друг̄иог̄ , како постоењето на фантазијата на Алис, каде што Бил е само гледач, воајер. „Секој контакт со вистинскиот Друг од 'крв и месо', секое сексуално задоволство кое го пронаоѓаме во допирот на друго човечко суштество, не е нешто евидентно, туку нешто наследено, трауматично и може да биде задржано сѐ додека Друг̄uо̄̄ навлегува во рамката на фантазијата на субјектот“" (Žižek 2006: 59).

Со својата исповед, Алис е таа која ја крши рамката на брачната постела, а за Бил тоа станува состојба за која не може да говори. Таа во длабочината на свеста за него е раскршена маска, персона или, најдобро речено, сопруга и верна љубовница. Иако исповедта е само фантазија, траумата од нејзиното постоење силно навлегува во свеста на Бил. Во соочувањето со реалноста, Бил ја открива фантазијата на Алис и кршењето на нејзината улога на верна жена која својот живот го насочила во целост кон него, како кон свој сопруг, кон мајчинството и домот. Токму пред него се разоткриваат пукнатините на маската која ги заштитува од реалноста. Во исто време, опозицијата меѓу сонот и реалноста се испревртува, фантазијата е на страната на реалноста, а во соништата се среќава трауматичното реално (Žižek 2006: 59). Сепак, брачната постела е местото каде што се случува оваа трауматична средба. Тоа е местото каде што нивните тела совршено се вклопуваат во сексуална 
исполнетост. Во интерпретацијата на филмот Очи ширко зайворени на Жижек се вели дека она што го искусуваме како реално е структурира на фантазијата, фантазијата користи како параван кој нѐ заштитува да не бидеме совладани од суровото реално, а самата реалност може да послужи како бегство од средбата со реалнойо. Токму во ова се согледуваат ноќните прошетки на Бил низ Њујорк, кои многу наликуваат на очајнички обид да се воспостави нова фантазија која ќе биде одговор на онаа фантазија за која говори Алис.

Фантазијата е платно кое нѐ заштитува од средбата со реалноста, самата фантазија, во својата основа - она што Фројд го нарекува „фундаментална фантазија“, која ги овозможува елементарните координати на способноста на субјектот за желба (посакување) - никогаш не може да биде субјективизирана и мора да остане репресирана со цел да функционира (Žižek 2006: 59).

Така ноќните прошетки на Бил се движат на границата меѓу сонот и реалноста. Ноќните прошетки стануваат мрачни, темноцрвени мизансцени и средби кои треба да ја решат енигмата на фантазијата на Алис и да конституираат нова силна фантазија која треба да ги спаси и двајцата. Жижек (Žižek 2006) објаснува дека сите средби и ситуации кои Бил ги остварува за време на неговите ноќни прошетки се обиди за креација на новата фантазија, но тие стануваат импотентни обиди за реализација.

Фантазијата се поврзува за страсната врска со ќерката на поранешниот пациент, која му изјавува љубов пред телото на нејзиниот штотуку починат татко, со средбата со чесната проститутка која не сака да ги прифати парите за нејзината неисполнета услуга, со продавачот на костими во продавницата „Виножито“ (познато ни е дека патеката на желбата води до исполнување во просторот зад виножитото, тука се алудира на Волмебникой og Оз и на добивањето влез пред големиот волшебник), кој ја продава сопствената ќерка, и конечно со оргиите во големата вила „Самертон“.

По средбата со пријателот од колеџ, Ник Најтингејл, пијанист, Бил добива информација за оваа ексклузивна и забранета забава и решава да обезбеди маска и облека соодветна за да земе учество во неа. Маскенбалот во „Самертон“ е огледалната слика на Божиќниот бал, тука сите се затскриени зад маските, елитната класа луѓе ги остварува своите сексуални фантазии. Токму во оваа фантазија, тој е заштитен со маската со која влегува во една средина каде што е натрапник, неговото откривање би значело негово уништување. Маскенбалот е место каде што сите посетители се доверливи луѓе, а тајната лозинка за влез е фиделио - (верност, но, во исто време, се алудира на опера на Лудвиг ван Бетовен во која една жена се преобразува во маж со цел да ја спаси својата љубов). Совршениот начин на режирање на Кјубирк, особено се согледува во реализацијата на оваа 
голема и долга секвенца каде што вилата Самертон станува место на најсилното подривање и неуспешноста на фантазијата и тоа преку еден пагански ритуал. Камерата ги снима сексуалните акти во еден долг кадар. Тој е снимен од нормален ракурс во кој се соединуваат очите на Бил и очите на гледачот, проследени со драматично напнатите мизансцени. Чекорењето на Бил е повторно т.н. барање на партнер за сексуален акт „како избор на облека во излог“ (Žižek 2001: 173-175). Тоа е, исто така, воајерски поглед кон машката сексуална фантазија за жените кои ги заведуваат мажите и нудат исполнување на секоја нивна сексуална фантазија. Но, воајеризмот е и фиксација на сексуалната фантазија која никогаш нема да биде исполнета, а како таква, таа во Самертон претставува нешто недозволено. Бил од набљудувач на сексуалните акти и пасивен посматрач станува оној кој е набљудуван, оној кој е друг и непосакуван и затоа неговата казна мора да биде кршење на маската која е несоодветна за ова место. Маската е симната, а неговиот живот е спасен благодарение на девојката која неколкупати ќе го предупреди на опасноста која го демне. Неуспехот на реализација и востановување на фантазијата во оваа сцена значи и конечен распад на ликот на Бил. Опасноста веќе ги надминува границите на ноќта и навлегува во секојдневниот живот на почитуваниот доктор Бил. Неуспехот да ја пронајде спасителката, смртта на убавицата, како и заканите по неговиот живот, како и разговорот со доминантниот (повеќе не пациент и пријател во неволја) Зиглер, на крајот го доведуваат до соочување со недовербата кон реалноста која повеќе никогаш не може да биде иста каква што ја замислувал. Маската која од Самертон е пренесена на перницата на брачната постела е симбол кој Кјубрик го воведува со цел да го предупреди Бил дека маската или улогата е она што може да го спаси. Исповедта пред Друг̄uой, пред Алис, е она што може да го ослободи Бил. Не зашто тоа е помирување и простување, напротив тоа е вербален доказ дека фантазијата на Бил е востановена и покрај неговите одбивања. Тој повеќе не сонува и неговите очи се широко отворени. И двајцата се соочени со вишокот на фантазии, тие мора веднаш да направат нешто за да ги ограничат. Алис е онаа која го нуди решението за нивното преживување, таа вели „Let's fuck”. Тоа е она што го поддржува преживувањето на Алис и Бил како двојка наспроти расцепот меѓу нив создаден од реалнойо кое упатува на тоа дека живееме со фантазиите. Според Жижек, овој лажен излез или фантазии е начин да се избегне соочувањето со хоророт на фантазмагоричното, тоа е подземен начин да се избегне соочувањето со напливот на непосакувани фантазии кои ќе останат празни. Жижек вели: „Тоа е, како нејзината порака да вели: ајде да се ебеме што е можно поскоро со цел да ги згаснеме нашите нараснувачки фантазии, пред тие да нѐ обземат“ (Žižek 2006: 59). Tој се повикува на Лакан и неговата шега во која вели дека будењето во 
реалноста е како бегство од реалнойо. Тоа може да се сретне во сонот, тоа е поверодостојно од сѐ, тоа е сопоставено на самиот сексуален чин (Lacan 1949: 146). Според Лакан, најголемата етичка задача е вистинското будење, но не од сонот, туку од магијата на фантазијата која нѐ контролира уште повеќе кога ние сме разбудени, т.е. кога очите ни се широко затворени (ibid, 146).

Говорејќи во таа насока, преминуваме на филмот Нейоврайно во чиј центар на приказната е траумата, анално силување на Алекс (референца кон ликот на Алекс од Пеколниой йройокал), што претставува насилство кое го приклештува гледачот во состојба во која треба да биде сведок на телото кое е уништено, крв, семена течност и солзи. Иако филмот е дел од т.н. „нов француски екстремизам“ (New French extremity), тој во својата приказна преку насилството ја обработува темата на траумата, но истовремено го прикажува и обезличувањето, и на телото, но и на персоната.

Парадоксалниот наслов Нейоврайно и приказната раскажана од крајот кон почетокот го приклештуваат гледачот во позиција на набљудувач без можност да го тргне погледот. Започнувајќи со движење на камерата и симнување од небото кон долу, до разговорот на Касапот (лик од претходниот филм на авторот под наслов Јас стиојам сам од 1999 година), кој вели дека во неговиот живот „нема лоши дела, туку само дела“, па сѐ до френетичното, лавиринтско движење на камерата низ ходниците „црева“ за задоволување на сексуалните нагони на посетителите на клубот „Ректум“, заедно со ликовите на Маркус (телото) и Пјер (умот), па сѐ до уништениот череп и деветминутното силување и претепување на Алекс, кадрирани така што чинот го зафаќа целиот филмски екран го формираат првиот дел од филмот. Изразеното црвено светло, трепкањето, нестабилноста на камерата пред гледачот претставува еден свет кој е дезинтегриран и кој со нарацијата постојано се враќа кон назад и ги пренесува реверзибилно сите информации.

Сведоштвото за траумата од страна на гледачот, кое е прикажано на филмското платно, ја определува траумата како настан кој се случува надвор од параметрите на „нормалната“ реалност. Во исто време, може да се каже дека овде станува збор и за естетска (ре)конструкција на една траума, траума за оној кој ја доживува и за оној кој ја гледа, но исто така „насилството станува моќно во ситуацијата кога истото е екранизирано и естетизирано. Оние кои го гледаат и оние кои го извршуваат насилството не се разликуваат во соучесништвото на гледањето и на извршувањето на истото дело“" (Felman and Laub 1991: 31). Во моментот кога насилството се извршува, Гаспар Ноа, во филмскиот кадар кој е исполнет со насилниот 
чин, го воведува и аспектот на набљудувачот (bystander) и во исто време ја проблематизира неговата позиција на сведок.

Де/естетизирањето на насилството кое го прикажува филмот Heйоврайно се случува во оној миг кога негов сведок станува гледачот чии очи се приклештени за екранот. Која е функцијата на насилството, ако траумата е средиштето на филмската нарација во една приказна која е раскажана од крајот кон почетокот? Дали навистина има крај и дали има почеток? Камерата во овој филм има исклучително долги и „напрегнати“ кадри кои наликуваат на кадри изведени на работ на епилептични напади, се симнуваат од горе, од небото и се враќаат горе на небото, со движење кое предизвикува непријатност и мачнина кај гледачот. Гледачот е сведокот на насилството, тој е оној кој не може да се извлече од позицијата на набљудувач, но иако филмот завршува со позитивна или „ведра“ секвенца каде што Маркус, Алекс и Пјер го живеат животот, приклештеноста на гледачот за приказната станува уште помачна, имено, „времето уништува cѐ“, зашто времето тече во спротивна насока, а гледачот знае дека тоа е насочено кон ужасниот настан.

Токму во оваа уништувачка сила на времето, филмот ја обележува депресивната помиреност со настаните, насилството или, подобро кажано, со уништувањето на телото, силувањето, обезличувањето и претепувањето. Па затоа прераскажувањето, реконструкцијата има ослободувачка моќ, но тоа потфрлање на јазикот е силно изразено, имено станува збор за искажување на немоќ пред напливот од насилство.

Двајцата љубовници на Алекс се Маркус (телото) и Пјер (разумот), но и двајцата не успеваат да ја спасат кога таа ќе се соочи со темниот црвен ходник и „Тенијата“ кој ја обезличува. Пјер е стариот љубовник чии приказни повеќе не ја возбудуваат. Неговата рационалност не успева да го замени телесното, да го достигне врвот на сексуалното доживување, туку е само одложување на тоа задоволство. Алекс во очите на Пјер е само естетско доживување. Но, Маркус, кој го претставува „телесното“, е оној кој го обезбедува тоа задоволство за Алекс. Но, во ниту еден момент, таа со ниту еден од нив не е среќна, не е исполнета жена. Дури и во моментот кога таа ќе започне да ја објаснува книгата што ја чита, нешто од кое таа тешко може да се оддели веднаш е прекината од незаинтересираноста која ја покажуваат подеднакво и Маркус, како и Пјер. Дури и разговорот на тројцата за сексот и задоволството се проектирани врз неа, врз нејзиното телесно доживување. Пјер го бара објаснувањето на задоволството кое Маркус ѝ го овозможува, а тој не умее. Стимулансите за ослободување кои и двајцата ги консумираат, таа ги презира. Секој нејзин исказ е пресретнат со негација, Пјер негира дека таа ја кажува вистината за достигнување на вистинско задоволство, а Маркус ја негира нејзината исповед за љубовниот 
живот кој го имала со Пјер. Замолчувањето на Алекс е замолчување пред двата аспекта кои не се помируваат и нивното инсистирање донесува краен распад. Ако Пјер не ја препознава нејзината потреба за телесно задоволство, тогаш Маркус не ја препознава нејзината потреба за искажување на сонот и ја прекрива нејзината уста, исто онака како што силувачот Тенија ѝ ја затвора устата додека го извршува половиот акт.

Навистина е интересно тоа што Алекс е онаа која ќе го доживее обезличувањето, на самиот крај (почетокот) на филмот ја чита книгата на J. В. Дан Ексиерименй со времет̄о, во која авторот зборува дека времето е мултидимензионално и дека во соништата, со помош на асоцијации, ги извлекуваме нашите искуства во минатото и проекциите во иднината. Режисерот Гаспар Ноа, мошне иронично, на самиот крај на филмот го преставува најинтимниот дел од животот на двојката Маркус и Алекс, нивниот кревет. Сцена која најсилно алудира на брачната двојка Алис и Бил од филмот Очи широко зайворени, која од место на сигурност и сексуалност станува место на измачување и децентрирање на фантазијата. Во креветот, нивните тела се прикажани во една длабока интимност, но таа телесна опресија е надмината кога нивните тела стануваат едно. Соништата кои се непријатни, како што е непријатно раскажувањето на сонот на Алекс за црвен ходник кој се распаѓa, а Маркус не ја чувствува својата рака, се два сигнала кои гледачот ги поврзува со телесните насилства врз овие два лика.

Ретроспективниот приказ на настаните во Нейоврайно во себе содржи еден вид на „исцелителна““ моќ, која од состојба на хаос и насилство, светот го враќа во идилична состојба. Алекс е бремена, радосна и исполнета жена, таа ја чита книгата што ја сака и се одмара на ледина полна со детски џагор.

Прераскажувањето во Нейоврайно особено е значајно зашто во себе ја раскажува, ја артикулира приказната, „буквално се пренесува некому надвор (на гледачот)“" и, на самиот крај, повторно во френетична состојба, под дејство на трепкачко светло кое предизвикува епилептични напади и силни звуци, таа приказна е апсорбирана од оној кој започнал со раскажувањето, таа му се враќа нему. „Кажувањето, според ова, наложува реафирмација на хегемонијата на реалноста и пре-раскажувањето над злото кое ѝ се случило и ја запоседнало жртвата од траумата“" (Felman and Laub 1991: 69).

Дванаесетте поглавја се изведени со ретроспективен приказ, насилството

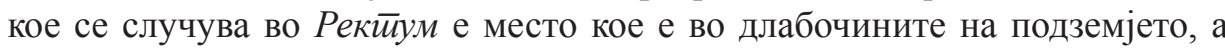
црвениот подземен премин е нереалниот простор, па затоа и двата настана се „надвор“ од параметрите на „нормалната“ реалност“, како што условеноста (каузалноста), последователноста „по однос на време и место“е дел од она што е живот во реалноста. Лакан ја објаснува психоанализата на Фројд во однос на „отворањето“ место за ретроспекција кај субјектот, простор за реструктурирање на настаните од минатото, „можност за преуредување 
на минатата непредвидливост со пренесување врз смислата во однос со потребите што надоаѓаат“ (Clift 2014: 186). Сепак, во психоанализата преку говорот, ретроспективата и навраќањето наназад се доаѓа до траумата, а потоа следи соочувањето, жалењето и на крајот ослободувањето. Според Бланшо,

(...) Нарациите не го објаснуваат трауматичното минато, туку, уште поточно, тие не успеваат во таа задача, зашто нарациите го израмнуваат времето и ги бришат димензиите на идноста, која е имплицитна во траумата, а која не може да биде ограничена во текот на нарацијата. (Clift 2015: 196-197)

Во нарацијата на овие наведени филмови, времето претставува основна појдовна точка врз која режисерот го поставува својот проблем. Ако Персона во својата нарација ги крши правилата на „кога“ и „каде“, освен бледите означители на временските рамки во кои Елизабет, актерката, е во кататонична состојба, тогаш пробивот на филмската лента, нејзиното пукање и артифициелност има за цел да нѐ врати во состојба која е надвор од филмското време. Ние сме гледачи на филмот, ние не ја преживуваме оваа приказна заедно со нив.

Уште поочигледно е сето тоа во односот сон-јаве, а со тоа и во времето како рамка на дејствата на ликовите Бети и Рита/Камила, во филмот Булевар на sвезguйе на Дејвид Линч. Патешествијата на ликовите во филмот на Дејвид Линч се вонвременски, а клучот за нивното разбирање е во гледачот кој треба да ги состави. Неубедливоста во постоењето на балот во Самертон е посилна дури од Бил, оној кој честопати ќе треба да се идентификува себеси како лекар и член на „Лекарскиот одбор на државата Њујорк“ (Just to let you know that I really am Dr. Harford, this is my New York State Medical Board Card) за да се постави во одредени координати на време/простор.

И на крај Нейоврайно е филм каде што од насилство и ужас, ретроспективно, скоро неверојатно, ние го враќаме првобитното време, кое ѝ претходело на траумата. Ако идентитетот на една личност се состои во формирањето низа различни конструкции кои треба да соодветствуваат во средбата со Друг̄иой, тогаш неминовно е да се зборува и за распаѓањето, кога средбата се остварува со нешто кое не соодветствува на реалноста. Идентитетот е граден според она што нам ни се чини добро, правилно и корисно и така можеме да се соочиме со реалноста.

Но кога траумата ја нарушува оваа конструкција, кога маската се крши, тогаш новото создавање на идентитетот бара голема жртва со цел повторно да се состави. 


\section{Библиографија}

Clift, S. (2014). Commiting to the future to memory: History, experience, memory. New York: Fordham University Press.

Felman, S. and Laub, D. (1997). Testimony: crises of witnessing in literature, psychoanalysis, and history. London: M. D.

Lacan, J. (2006). The mirror stage as formative of the function as revealed in psychoanalytic experience. In B. Fink (transl.). Écrits ( $1^{\text {st }}$ complete edition in English), 1-7. New York and London: W. W. Norton and Company.

Sontag, S. (2000). Bergman's persona. In S. L. Michaels (ed.). Ingmar Bergman's persona, 61-86. Cambridge: Cambridge University Press.

Žižek, S. (2001). The fright of real tears: Krzysztof Kieslowski between theory and post theory. London: BFI Publishing.

Žižek, S. (2006). How to read Lacan: From Che vuoi? to Fantasy. New York: W.W. Norton \& Company. 